\title{
Examination of Teachers' Perceptions about Servant Leadership and Organizational Commitment
}

\author{
Ayşegül Palta ${ }^{1}$ \\ ${ }^{1}$ Faculty of Education, Hakkari University, Hakkari, Turkey \\ Correspondence: Ayşegül Palta, Faculty of Education, Hakkari University, Hakkari, Turkey.
}

Received: November 15, 2018

Accepted: December 19, $2018 \quad$ Online Published: March 10, 2019

doi:10.5539/ies.v12n4p36

URL: https://doi.org/10.5539/ies.v12n4p36

\begin{abstract}
The issue of leadership has been debated by people since ancient times. When literature review is done in this field, it has seen that leadership was defined by many scientists and different approaches have been created about the subject Servant leadership is an understanding that reappears in the modern world and that leaders are accountable to their followers and go back to historical antiquity. Organizational commitment is the degree of integration and identification that an individual feels for an organization. Many researches have been done so far on organizational commitment. Low organizational commitment has individual and organizational negative consequences such as being late for work, absenteeism, low performance and even leaving the job. The purpose of this study is to investigate teachers' perceptions about servant leadership and organizational commitment. 149 teachers answered the scales. Survey and correlational model were preferred. According to the findings, teachers' perceptions about servant leadership and organizational commitment don't vary in accordance with gender, branch, tenure in school and seniority. Organizational commitment of teachers and servant leadership perceptions are related to each other. This relationship is positive and low.
\end{abstract}

Keywords: organizational commitment, servant leadership, teacher

\section{Introduction}

In the rapidly changing competitive environment of today, it has become very difficult for organizations to perform long-term successful performance and to use their resources effectively. In achieving this, the concept of servant leadership has recently attracted attention by keeping an important place in the field of organization management. Servant leadership differs from other leadership structures, with other important leadership theories as conceptual overlap with transformative, ethical, charismatic leadership, but by focusing specifically on the needs of its followers and stakeholders, and by helping them to develop and grow.

The issue of leadership has been debated by people since ancient times. When literature review is done in this field, it has seen that leadership was defined by many scientists and different approaches have been created about the subject (Dilek, 2005). In 1970, Robert Greenleaf introduced the concept of servant leadership and became the name of the book which he published in 1977. According to Greenleaf, the core and primary responsibility of servant leadership is to serve the subordinates and their organization. The concept of serving here is the development, defense and empowerment of subordinates. A serving leader should be more responsive to the needs of his / her subordinates and help them to become healthier, smarter and more willing to take responsibility. Even if such a leader is not in line with the financial interests of the organization, he should be able to represent good and righteousness and, when necessary, be able to resist social injustice and inequality (Güney, 2006; Yukl, 2010).

The concept of servant leadership actually consists of basic and eternal principles applied in all cultures for many years (Sendjaya \& Sarros, 2002). Servant leadership is an understanding that reappears in the modern world and that leaders are accountable to their followers and go back to historical antiquity (Davies, 2007). Patterson (2003) lists the characteristics of servant leaders as virtue and high moral virtues, a personality that strives for honesty and goodness. One of the most important sources of servant leadership is his personality.

Akyüz (2014) defines servant leadership as a new leadership model that creates changes in people who direct and manage individuals. Spears (1995) listed ten personal characteristics of servant leaders as follows: listening, sympathy, improvement, awareness, persuasion, conceptualization, forward-thinking, self-determination, devotion to human development, and community formation. The most important feature that distinguishes servant 
leadership from others is to help people to complete, eliminate deficiencies, and to create added value (Akoğlan, 2011).

While organizational commitment affects the efficiency of the organization significantly, the leadership styles demonstrated by the managers affect the employees' commitment to the organization. Organizational commitment is the degree of integration and identification that an individual feels for an organization (Arl, 2003). Although organizational commitment has been studied in many dimensions by many researchers, most of the recent research has used the organizational commitment model developed by Allen and Mayer. In a study by Mayer and Allen (1991), they obtained three factors: emotional, continuity and normative. People with emotional commitment, they want and want; People with continuity, they need; People with normative, they feel obligation in organization.

Many researches have been done so far on organizational commitment. Low organizational commitment has individual and organizational negative consequences such as being late for work, absenteeism, low performance and even leaving the job (Gül \& İnce, 2005). It is believed that the employees with organizational commitment will work more and make more sacrifices for the achievement of the organizational goals (Meyer \& Allen, 2004).

This research is important in terms of these two variables affecting the effectiveness and efficiency of the organization in terms of educational institutions, revealing these variables in a theoretical and research based on descriptive research method and guiding the school administrators and teachers. The problems are as below:

- Do teachers' perceptions about servant leadership and organizational commitment vary in accordance with their gender?

- Do teachers' perceptions about servant leadership and organizational commitment vary in accordance with their branch?

- Do teachers' perceptions about servant leadership and organizational commitment vary in accordance with their tenure in school?

- Do teachers' perceptions about servant leadership and organizational commitment vary in accordance with their seniority?

- Is there a significant relationship between teachers' perceptions about servant leadership and organizational commitment?

\section{Method}

\subsection{Research Model}

Research model is survey model because investigate the differences between perceptions about servant leadership and organizational commitment in accordance with gender, seniority, tenure in school and branch. Survey model was supply to understand people's attitudes, beliefs and so on (Mcmillan \& Schumacher, 2001). The study's model is also correlational to understand relation between teachers' perceptions about servant leadership and organizational commitment. Correlational studies supply relationships between variables and researcher use correlational statistics (Balc1, 2011).

\subsection{Population and Sample}

The population of research consists of teachers. The convenience sampling method was used and 149 teachers answered the scales. This method supply researcher easiness about money, time and workforce (Büyüköztürk, Kılıç, Akgün, Karadeniz, \& Demirel, 2011).

Table 1. Demographic information of participants

\begin{tabular}{lccc}
\hline Variable & Groups & $\mathrm{n}$ & $\%$ \\
\hline \multirow{3}{*}{ Gender } & Male & 79 & 53.0 \\
& Female & 70 & 47.0 \\
& Total & 149 & 100.0 \\
Branch & Branch teacher & 61 & 40.9 \\
& Classroom teacher & 88 & 59.1 \\
& Total & 149 & 100.0 \\
Tenure in school & 1-5 years & 4 & 2.7 \\
& 6-10 years & 15 & 10.1 \\
& $11-15$ years & 39 & 26.2 \\
& $16-20$ years & 36 & 24.2 \\
\hline
\end{tabular}




\begin{tabular}{cccc}
\hline & 21 years and over & 55 & 36.9 \\
Total & 149 & 100.0 \\
1-5 years & 71 & 47.7 \\
Seniority & 6-10 years & 35 & 23.5 \\
& $11-15$ years & 28 & 18.8 \\
& 16-20 years & 13 & 8.7 \\
& 21 years and over & 2 & 1.3 \\
Total & 149 & 100.0 \\
\hline
\end{tabular}

The frequencies and percentages are given in accordance with gender, branch, tenure in school, seniority.

\subsection{Instruments}

In this study, the Servant Leadership Scale which was developed by Girard (2000) and adapted to Turkish by Cerit (2005) was used. The scale consists of 9 dimensions and 28 items. It is Likert type scale. The alpha value for the whole scale is 95 .

In this study, the Organizational Commitment Scale which was developed Allen \& Meyer (1990) and adapted to Turkish by Doğan (2008) was also used. The scale consists of 3 dimensions and 24 items. It is Likert type scale. The alpha value for the whole scale is 78 .

\subsection{Analyses}

Independent Samples T Test, Kruskal Wallis Test and Pearson Product Moment Correlation Coefficient were used while analyzing the data. In this study, it was assumed that teachers answered internally the questions in the applied scale. The research is limited to the teachers working in primary and secondary schools in Mersin. The findings are limited to the qualities measured by the scales.

\section{Results}

Data obtained from scales were analyzed. Findings are as follows:

Table 2. Teachers' perceptions about servant leadership and organizational commitment in accordance with gender

\begin{tabular}{lcccccc}
\hline Points & Gender & $\mathrm{N}$ & Mean & Std. Deviation & $\mathrm{t}$ & $\mathrm{p}$ \\
\hline \multirow{2}{*}{ Organizational Commitment } & Male & 79 & 76.0886 & 11.30826 & 1.37 & .17 \\
& Female & 70 & 73.7429 & 9.31834 & & \\
\multirow{3}{*}{ Servant Leadership } & Male & 79 & 115.8608 & 22.58757 & 1.19 & .23 \\
& Female & 70 & 111.6000 & 20.64075 & & \\
\hline
\end{tabular}

Teachers' perceptions about servant leadership and organizational commitment don't vary in accordance with gender $(\mathrm{p}>.05)$. The points of male and female teachers seem similar.

Table 3. Teachers' perceptions about servant leadership and organizational commitment in accordance with branch

\begin{tabular}{lcccccc}
\hline Points & Branch & $\mathrm{N}$ & Mean & Std. Deviation & $\mathrm{t}$ & $\mathrm{p}$ \\
\hline \multirow{2}{*}{ Organizational Commitment } & Branch & 61 & 73.6066 & 6.10540 & -1.50 & .13 \\
& Classroom & 88 & 75.9432 & 12.56556 & & \\
\multirow{2}{*}{ Servant Leadership } & Branch & 61 & 112.5574 & 22.33124 & -.60 & .54 \\
& Classroom & 88 & 114.7614 & 21.38051 & & \\
\hline
\end{tabular}

Teachers' perceptions about servant leadership and organizational commitment don't vary according to branch ( $>$ >05). The points of branch and classroom teachers seem similar. 
Table 4. Teachers' perceptions about servant leadership and organizational commitment in accordance with tenure in school

\begin{tabular}{lccccc}
\hline Points & Tenure in school & $\mathrm{N}$ & Mean Rank & $\mathrm{X}^{2}$ & $\mathrm{p}$ \\
\hline \multirow{4}{*}{ Organizational Commitment } & 1-5 years & 71 & 74.13 & 1.67 & .79 \\
& 6-10 years & 35 & 69.60 & & \\
& $11-15$ years & 28 & 78.18 & & \\
& $16-20$ years & 13 & 86.08 & & \\
& 21 years and over & 2 & 83.75 & & \\
& $1-5$ years & 71 & 77.27 & 1.87 & .76 \\
Servant Leadership & 6-10 years & 35 & 74.76 & & \\
& $11-15$ years & 28 & 67.73 & & \\
& $16-20$ years & 13 & 74.50 & & \\
& 21 years and over & 2 & 103.50 & & \\
\hline
\end{tabular}

Teachers' perceptions about servant leadership and organizational commitment don't vary in accordance with tenure in school ( $p>05)$. The points of teachers have different tenures seem similar.

Table 5. Teachers' perceptions about servant leadership and organizational commitment in accordance with seniority

\begin{tabular}{lccccc}
\hline Points & Seniority & $\mathrm{N}$ & Mean Rank & $\mathrm{X}^{2}$ & $\mathrm{p}$ \\
\hline \multirow{4}{*}{ Organizational Commitment } & 1-5 years & 4 & 86.50 & 2.87 & .58 \\
& 6-10 years & 15 & 91.47 & & \\
& $11-15$ years & 39 & 72.71 & & \\
& $16-20$ years & 36 & 71.63 & & \\
& 21 years and over & 55 & 73.51 & & \\
& $1-5$ years & 4 & 87.50 & 2.33 & .67 \\
Servant Leadership & 6-10 years & 15 & 80.80 & & \\
& $11-15$ years & 39 & 74.01 & & \\
& 16-20 years & 36 & 81.10 & & \\
& 21 years and over & 55 & 69.22 & & \\
\hline
\end{tabular}

Teachers' perceptions about servant leadership and organizational commitment don't vary in accordance with seniority $(\mathrm{p}>.05)$. The points of teachers have different seniorities seem similar.

Table 6. Relationship between teachers' perceptions about servant leadership and organizational commitment

\begin{tabular}{lccc}
\hline & & Organizational Commitment & Servant Leadership \\
\hline \multirow{3}{*}{ Organizational Commitment } & Pearson Correlation & 1 & $.180^{*}$ \\
& Sig. (2-tailed) & & .028 \\
& $\mathrm{~N}$ & 149 & 149 \\
& Pearson Correlation & $.180^{*}$ & 1 \\
Servant Leadership & Sig. (2-tailed) & .028 & \\
& $\mathrm{~N}$ & 149 & 149 \\
\hline
\end{tabular}

Organizational commitment of teachers and servant leadership perceptions are related to each other. This relationship is positive and low.

\section{Discussion}

In accordance with the findings: teachers' perceptions about servant leadership and organizational commitment don't vary in accordance with gender. According to Kılıç and Portakal (2016), servant leadership and organizational engagement differ according to gender variable. Doğan and Aslan (2016) found that teachers 'organizational engagement differ significantly according to gender. It was also found that the servant leadership levels perceived by the teachers according to their gender differ significantly. In İş and Balcı's (2017) study, there was a significant difference in the perceptions of teachers about the servant leadership according to gender. 
According to Nacar and Demirtaş (2017), the organizational commitment of teachers is different according to gender. Gören and Sarpkaya (2014) found no significant difference in the normative and continuity commitment of managers and teachers according to gender variable, but found a difference in their emotional commitment.

Teachers' perceptions about servant leadership and organizational commitment don't vary in accordance with branch. According to Nacar and Demirtaş (2017), the branches of the participants did not have a significant effect on organizational commitment. According to Gören and Sarpkaya (2014), there were significant differences in the three levels of commitment of directors and teachers according to branch variable.

Teachers' perceptions about servant leadership and organizational commitment don't vary in accordance with tenure in school. Teachers' perceptions about servant leadership and organizational commitment don't vary in accordance with seniority. In İş and Balcı's (2017) study, there was a significant difference in the perceptions of teachers about the servant leadership according to the variables of seniority and school type, but there was no significant difference in the age variable. According to Gören and Sarpkaya (2014), there were significant differences between administrators and teachers according to seniority variable in all three levels of commitment. According to Nacar and Demirtaş (2017), age, seniority of participants did not have a significant effect on their perception of organizational commitment.

Organizational commitment of teachers and servant leadership perceptions are related to each other. This relationship is positive and low. Yllmaz and Ceylan (2016) found a significant relationship between servant leadership and organizational commitment. Örücü and Teker (2014) found that there is a significant relation between leadership and organizational commitment. Kılıç and Portakal (2016) found servant leadership effects on organizational commitment components (normative, emotional and commitment to continue). Doğan \& Aslan (2016) found a high level, positive and significant relationship between the organizational commitment levels of the teachers working in private education institutions and their managers' perceived servant leadership levels. Dal and Çorbacıoglu (2014) concluded that there is a significant and positive relationship between servant leadership and the interaction between leader and follower.

Research can be re-studied with larger samples for future studies. It should be taken into consideration that the research is only evaluated over the data of a specific time period. As this study is conducted only in a specific region in the province of Mersin, it is beneficial to do this in different schools in different provinces or in different schools in Mersin.

\section{References}

Akoğlan, M. (2011). Woman and leadership. Turizm Güncel. Retrieved from https://www.turizmguncel.com/makale/-kadin-ve-liderlik--m499.html

Akyüz, B. (2014). Servant leadership in management. Ankara: Gece.

Allen, N. J., \& Meyer, J. P. (1990). The measurement and antecedents of affective, continuance and normative commitment to he organisation. Journal of Occupational Psychology, 63(1), 1-18. https://doi.org/10.1111/j.2044-8325.1990.tb00506.x

Arı, G. (2003). Does the trust for the manager increase organizational commitment? Gazi University Journal of Trade Tourism Education Faculty, 2(22).

Balc1, A. (2011). Social science research methods, techniques and principles. Ankara: Pegem Akademi.

Büyüköztürk, Ş., Kılıç, E., Akgün, Ö., Karadeniz, Ş., \& Demirel, F. (2011). Scientific research methods. Ankara: Pegem Akademi.

Cerit, Y. (2005). Primary school principals levels of implementation servant leadership behaviors. Ege Education Journal, 6(2), 1-19

Dal, L. \& Çorbacioğlu, S. (2014). The relationship between servant leadership behaviors and leader-member exchange: A research on a state university. Suleyman Demirel University Journal of Faculty of Economics Administrative Sciences, 19(4).

Davies, A. (2007). Best practice in corporate governance. Burlington: Gower.

Dilek, H. (2005). A research on the effects of leadership styles and perception of justice on organizational commitment, job satisfaction and organizational citizenship behavior ( $\mathrm{PhD}$ Thesis, Gebze Institute of Technology, Institute of Social Sciences, Kocaeli).

Doğan, A. (2008). The effect of organizational justice on organizational commitment in primary education institutions (Master thesis, Firat University, Institute of Social Sciences, Elazığ). 
Doğan, Ü., \& Aslan, H. (2016). Relationship between the special education teachers' organizational commitment level and the perceieved level of servant leadership of administrators. Ondokuz Mayis University Journal of Faculty of Education, 35(2), 51-68.

Girard, S. H. (2000). Servant leadership qualities exhibited by Illinois public school district superintendents. Dissertation Abstracts International.

Gören, T., \& Sarpkaya, P. (2014). The level of organizational commitment of the teachers in primary schools in Aydın. Journal of Educational Sciences, 40, 69-87.

Gül, H., \& İnce, M. (2005). A new paradigm in management: Organizational commitment. Konya: Çizgi.

Güney, S. (2006). Conceptualization of moral leadership and leadership role in moral management. Celal Bayar Üniversitesi Yönetim ve Ekonomi Dergisi, 13(1),135-148.

Iş, E., \& Balcı, S. (2017). Assessment of school principals' (primary, secondary and high school) dimensions of servant leadership behavior according to teacher perceptions. The Journal of International Social Research, 10(50), 517-529.

Kılıç, C., \& Portakal, S. (2016). Effects of servant leadership on organizational commitment: A case of travel agencies in Gaziantep province. Ç.U. Journal of Social Sciences Institute, 25(2), 199-212.

Mcmillan, J. H., \& Schumacher, S. (2001). Research in education. A conceptual introduction (5th ed.). New York: Addison Wesley Longman Inc.

Meyer, J. P., \& Allen, N. J. (1991). A three-component conceptualization of organizational commitment. Human Resource Management Review, 1, 61-89. https://doi.org/10.1016/1053-4822(91)90011-Z

Meyer, J. P., \& Allen, N. J. (2004). TCM employee commitment survey. Academic Users Guide.

Nacar, D., \& Demirtaş, Z. (2017). Organizational commitment level of high school teachers. International Journal of Turkish Education Sciences, 5(9), 547-558.

Örücü, E., \& Teker, S. (2014) A research on analyzing relationship between leadership and organizational commitment in Turkey's hospitals. Journal of Management and Economics Research, 24, 73-90. https://doi.org/10.11611/JMER299

Patterson, A. (2003). Servant leadership: A theoretical model (Unpublished doctoral dissertation). Regent University, Virginia.

Sendjaya, S., \& Sarros, C. J. (2002). Servant leadership: Its origin, development and application in organizations. $\begin{array}{llll}\text { Journal of Leadership and Organizational Studies, } & \text { 9(2), }\end{array}$ https://doi.org/10.1177/107179190200900205

Spears, L. C. (1995). Reflections on leadership: How Robert $k$. Greenleaf's theory of servant leadership influenced today's top management thinkers. New York: Wiley.

Y1lmaz, C., \& Ceylan, A. (2016). A survey through the relationship between servant leadership and organizational commitment. Ylldiz Social Science Review, 2(2), 75-90.

Yukl, G. (2010). Leadership in Organizations (7th ed.). Pearson: Prentice Hall, Upper Saddle River. New Jersey.

\section{Copyrights}

Copyright for this article is retained by the author(s), with first publication rights granted to the journal.

This is an open-access article distributed under the terms and conditions of the Creative Commons Attribution license (http://creativecommons.org/licenses/by/4.0/). 